\title{
Comparative Study of Concentration of Some Minerals in Milk and Blood Plasma of Sheep and Goats Native and Foreign During Post-Partum Period under Climatic Conditions of Upper Egypt Damarany, A. I. \\ Department of Animal and Poultry Production, Faculty of Agriculture and Natural Resources, Aswan University, Egypt.
}

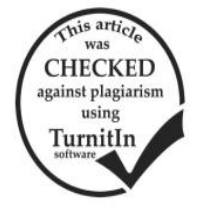

\begin{abstract}
The present study aimed to determine concentrations of sodium, potassium, copper and zinc in milk and blood plasma of Awassi, Baladi ewes and Boer, Baladi goats during the winter and summer seasons. Used in this experiment number of 180 ewes and goats. The blood and milk samples were taken after one month post partum. The samples were stored at $-18{ }^{\circ} \mathrm{C}$ till time of analysis. The minerals were determined by Atomic Absorption Spectrophotometer used to estimate copper and zinc and Flame Emission Photometry was used for estimation of sodium and potassium. The overall concentrations of (sodium, potassium, copper and zinc) in milk of Awassi and Baladi ewes were (533.8 $\pm 13.3,493.9 \pm 13.0,1475.0 \pm 20.4,1372.6 \pm 26.3,0.740 \pm 0.15$, $0.442 \pm 0.20,6.8 \pm 0.7$ and $5.4 \pm 0.6 \mathrm{mg} / \mathrm{l})$, while in blood plasma were $(2321.5 \pm 10.8,2034.3 \pm 8.8,186.2 \pm 1.1,142.5 \pm 2.3$, $0.87 \pm 0.01,0.51 \pm 0.02,1.72 \pm 0.01$ and $0.56 \pm 0.02 \mathrm{mg} / \mathrm{l})$ respectively. Meanwhile, concentrations of sodium, potassium, copper and zinc in milk of Boer and Baladi goats were $(541.0 \pm 15.6,455.6 \pm 14.3,1660.3 \pm 19.5,1511.5 \pm 13.9,0.718 \pm 0.25,0.426 \pm$ $0.30,3.2 \pm 0.3$ and $2.7 \pm 0.3 \mathrm{mg} / \mathrm{l})$, while in blood plasma were $(3263.7 \pm 11.3,1885.8 \pm 11.3,203.05 \pm 1.7,161.6 \pm 1.6,0.89 \pm 0.01$ $0.55 \pm 0.01,1.1 \pm 0.01$ and $0.51 \pm 0.01 \mathrm{mg} / \mathrm{l})$ respectively. The present results display that concentrations of sodium, potassium, copper and zinc in milk and blood plasma were higher in Awassi ewes and Boer goats compared with Baladi ewes and goats. Concentrations of studied elements in milk and blood plasma during the summer season recorded lower levels than winter season in ewes and goats. Thus, the study recommended supplementation of mixture of salts to diet of animals during the summer season in order to conservation of the minerals concentration in the normal levels in milk or blood. In addition, the assay of the studied minerals (sodium, potassium, copper and zinc) in milk compared with blood plasma is more easy and also accurate in ewes and goats.
\end{abstract}

Keywords: Minerals, milk, blood plasma, ewes, goats, winter, summer season

\section{INTRODUCTION}

Awassi sheep and Boer goat's considered as meat breeds were entered to Upper Egypt recently in order to improve the local breed by the crossing between them. Awassi sheep is a local breed distribute in South-West Asia (Iraq, Jordan, Syria, Lebanon and Palestine) Talafha and Ababneh (2011). Boer goats evolved in Southern Africa from indigenous African goats Casey and Van Nierkerk (1988), this breeds are breeding as a meat breeds in addition to acclimation, adaptation, and low parasite infestation Erasmus (2000). Minerals are required for all biological process of animal body functions. Its apart of enzymes structure in addition to regulate many chemical reactions (Ahmed et al., 2000 and Krajnicakova et al., 2003). Milk composition of ewes and goats depends on the feed, breed, lactation stage, individual animal, status of udder health and other environmental factors Park et al. (2007) and Sanz Ceballos et al. (2009). Several studies assess the minerals in ewes milk (Gerchev and Mihaylova, 2012; Catarino et al., 2013 and El-bagermi et al., 2014) and goats milk (El-bagermi et al., 2014; Ojoawo and Akinsoyinu, 2014 and Hernandz and Park, 2014). Recently some researchers determined the minerals in plasma of ewes and goats (Hassabo et al., 2015; Ebrahim et al., 2016 and Samadieh et al., 2017). There is limited information about concentration of minerals in milk and blood in ewes and goats that rearing under Upper Egypt conditions. In the light of the previous fact, the present study planned to investigate the concentration of minerals in milk and plasma of (Awassi, Baladi ewes and Boer, Baladi goats) reared under climatic conditions of Upper Egypt.

\section{MATERIALS AND METHODS}

\section{Location and Climate}

This study was carried out in Aswan governorate; it's far $890 \mathrm{~km}$ south from Cairo. The experimental period was extended from (May to August) as summer months and from (November to February) as winter months. The Ambient temperature (o C) during the summer season was (Max (35.9 - 44.3), Min (20.8 26.2)) while $(\operatorname{Max}(22.9$ - 35.0), Min (8.8 - 19.1)) during the winter season. Relative humidity (\%) during the summer and winter season was $(16-26)$ and (18-40) respectively. The climatic data was collected from The Meteorological Authority, Aswan.

\section{Animals and feeding}

The total number of experimental animals 180 (45 Awassi and 45 Baladi ewes) and (45 Boer and 45 Baladi goats). Age and parity of animals ranged between 2 to 3 year and 2nd to 4 th , respectively. Live body weights of the experimental animals were showed in table ( 1 ). The animals raised in a semi shaded open yards, and were fed on concentrate feed mixture (corn and wheat bran), Alfa-Alfa, and Barseem hay, the animals were fed adlibtum. Functions and symptoms of deficiency of (Sodium, Potassium, Copper and Zinc) on sheep and goats were showed in table (2).

Table 1. Means of live body weight of the experimental animals.

\begin{tabular}{lcc}
\hline Breeds & Range & Mean \pm SE \\
\hline Awassi & Ewes & \\
Baladi & $40-60$ & $48.5 \pm 5.97$ \\
\hline Boer & $30-42$ & $36.73 \pm 3.85$ \\
Baladi & Goats & \\
\hline
\end{tabular}


Damarany, A. I.

Table 2. Functions and symptoms of deficiency of minerals on sheep and goats (National Research Council,1980).

Element

Sodium Function

Potassium

Electrolyte, nerve impulse transmission

Electrolyte, nerve impulse transmission

Copper Many enzyme systems, hemoglobin formation, cartilage/bone formation

Zinc Epidermal tissues, skeletal formation healing

\section{Deficiency}

Common in grazing cattle, depressed appetite

Rapid decline in feed and water intake, loss of vigour, pica

Poor or faded hair, reduced growth, lameness

Poor reproduction, rough skin, poor immune function, reduced intake growth

National Research Council (1980). Mineral Tolerance of Domestic Animals, Washington, D.C. National Academy of Sciences.

Blood, milk and diet samples collection and determination of minerals

Blood samples $(10 \mathrm{ml})$ were collected from the jugular vein from all ewes and goats into heparinized tubes. Plasma collected upon centrifugation at $3000 \mathrm{rpm}$ for 10 min, and stored at $-18^{\circ} \mathrm{C}$ until analyzed. Milk samples (50 $\mathrm{ml})$ were collected from all experimental animals $(\mathrm{n}=180)$ and stored till the analysis; all the blood and milk samples were taken at the morning, after one month post-partum. The diets of animals were analyzed Table (3). The minerals were determined by Atomic Absorption Spectrophotometer (AAS) (ICE 3000C113500040 v1.30, England) used to estimate copper and zinc and Flame Emission Photometry was used for estimation of sodium and potassium. Minerals were analyzed according to (AOAC, 2000).

Table 3. Analysis of sodium, potassium, copper and zinc elements in green and dray forages throughout the experimental period.

\begin{tabular}{|c|c|c|c|c|}
\hline Element & Alfa-Alfa & Barseem hay & $\begin{array}{l}\text { Concentrate feed } \\
\text { mixture }\end{array}$ & Critical level in Blood (ppm) \\
\hline Sodium meq/kg DM & $130.5-152.3$ & $261-304.5$ & $226.2-243.6$ & - \\
\hline Potassium meq/kg DM & $409.6-435.2$ & $281.6-332.8$ & $163.8-171.5$ & - \\
\hline Copper $(\mathrm{mg} / \mathrm{kg})$ & $15.3-21.2$ & $8.7-16.4$ & $11.1-16.3$ & 0.6 \\
\hline $\operatorname{Zinc}(\mathrm{mg} / \mathrm{kg})$ & $10.6-16.5$ & $7.2-14.2$ & $14.5-18.7$ & 0.6 \\
\hline
\end{tabular}

*McDowell, L.R. 1985. Nutrition of grazing ruminants in warm climates. Academic Press Inc. San Diego CA. p. 168-169.

\section{Statistical analysis:}

Data were analyzed to the effect of season of the year on concentrations of minerals in milk and blood plasma of (Awassi and Baladi ewes, Boer and Baladi goats) using the general linear model procedure (SAS, 2002). Significance among the means was checked using T. test and Chi Squire was performed. The used model was:

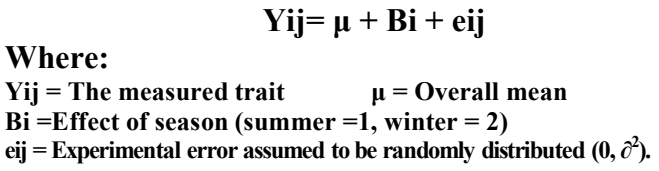

\section{RESULTS AND DISCUSSION}

I-Minerals concentrations in milk of ewes and goats Sodium concentrations in milk of ewes

Sodium concentrations in milk of ewes are presented in Table (4). The mean of sodium concentrations in milk were higher of Awassi than Baladi ewes $(P<0.05)$. The obtained averages were agree with that reported by Moreno-Rojas et al. ( 2009), Goran et al.( 2010) and Gerchev and Mihaylova (2012) they reported a concentrations of sodium in ewes milk ranged between (490 and $543 \mathrm{mg} / \mathrm{l}$ ). While, concentrations of sodium in ewes milk were lower than that reported by (Sahan et al., 2005 and Catarino et al., 2013) found that sodium concentrations were ranged between 612.0 and $743.0 \mathrm{mg} / \mathrm{l}$. This result may be due to different conditions around the study like (breed difference, nutrition, climate, season, lactation stag and heat tolerance). From table (4) concentrations of sodium in milk of ewes were higher $(P$ $<0.05$ ), during the winter than summer season. Similar trend was reported by Nantapo et al. (2013) who found concentration of sodium was higher in milk of ewes in the cold season than hot season.

\section{Sodium concentrations in milk of goats}

Concentrations of sodium in milk of goats are presented in Table (4). Concentrations of milk sodium were higher of Boer goats than Baladi goats ( $P$ $<0.05$ ), Table (4) . The results were close to that reported by Kedzierska -Matysek et al. (2013) and Hernandz and Park (2014) who found milk sodium in goats ranged between (464.0 and $545.2 \mathrm{mg} / \mathrm{l})$. Meanwhile it was higher than that reported by Park et al. (2007) and Moreno-Rojas et al. (2009) (410 - $440.0 \mathrm{mg} / \mathrm{kg})$ in goats milk. On the other hand, the present result was lower than that reported by Guzeler et al. (2010) and Ojoawo and Akinsoyinu (2014) (670.5 and $882.0 \mathrm{mg} / \mathrm{l})$. The different between concentrations of sodium in milk of goats may be due to experimental conditions, Sanz Ceballos et al. (2009) reported that milk composition of goats depends on the feed, breed, lactation stage, individual animal, status of udder health and other environmental factors. There is a significant difference $(P<0.05)$ in concentrations of sodium in milk of goats during two seasons summer and winter Table (4). Nantapo et al. (2013) found that no difference in concentration of sodium in milk of goats during the seasons of the year.

Table 4. Mean $\pm \mathrm{SE}(\mathrm{mg} / \mathrm{l})$ of sodium in milk of ewes and goats during summer and winter season.

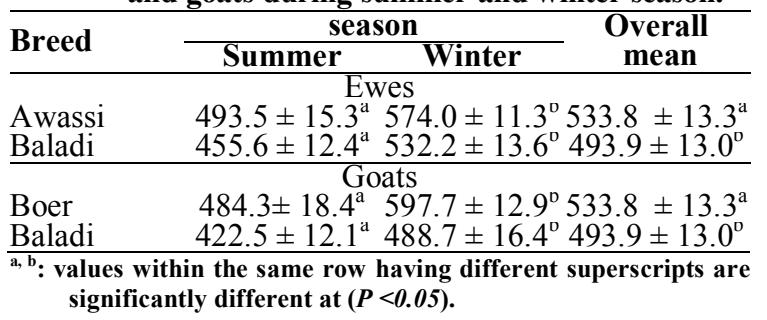

Potassium concentrations in milk of ewes

Concentrations of potassium in milk of ewes are presented in Table (5). Concentrations of potassium in 
milk of Awassi ewes were higher $(1475.0 \pm 20.4 \mathrm{mg} / \mathrm{l})$ compared with Baladi ewes (1372.6 $\pm 26.3 \mathrm{mg} / \mathrm{l})(P$ $<0.05)$. The result was agrees with that reported by Raynal-Ljutovac et al. (2008) who found that concentrations of potassium in milk of ewes were ranged between $(1360$ and $1400 \mathrm{mg} / \mathrm{l})$. Lower concentrations of potassium in milk of ewes reported by Sahan et al. (2005), Catarino et al. (2013) and El-bagermi et al. ( 2014) (593.9 and $1199.0 \mathrm{mg} / 1$. On contrary, higher concentrations of potassium in milk of ewes reported by Moreno-Rojas et al. (2009), Goran et al. (2010) and Zamberlin et al (2012) (1570 to $2137.7 \mathrm{mg} / \mathrm{l}$. The different in concentrations of potassium in milk of ewes compared to the previous works may be due to the different of breed, content of food from minerals and content of soil from minerals. Park et al. (2007) found that milk composition of ewes affected by the feed, lactation stage, breed, status of udder health, individual animal, and other environmental factors. Concentrations of potassium in milk of ewes during winter season were higher $(1530 \pm 18.4,1390.7 \pm 28.4 \mathrm{mg} / \mathrm{l})$ than summer season $(1420 \pm 22.4,1354.5 \pm 24.2 \mathrm{mg} / \mathrm{l})(P$ $<0.05)$. There is a significant difference $(P<0.05)$ in concentrations of potassium in milk of ewes during two season summer and winter table (5). Similar result reported by Nantapo et al. (2013) in the cold and hot seasons.

Potassium concentrations in milk of goats

Potassium concentrations in milk of goats are presented in Table (5). The present means of potassium concentrations in milk of Boer goats were higher (1660.3 \pm $19.5 \mathrm{mg} / \mathrm{l})$ compared with Baladi goats $(1511.5 \pm 13.9$ $\mathrm{mg} / \mathrm{l}) \quad(P<0.05)$. The present mean of potassium concentrations in milk agrees with that reported by Moreno-Rojas et al. (2009), Guzeler et al. (2010) and Ojoawo and Akinsoyinu (2014) (1460.0 - 1630.0 mg/l). Higher concentrations of potassium were reported by Kedzierska -Matysek et al. (2013) and Hernandz and Park (2014) (1717.0 and $1968.0 \mathrm{mg} / \mathrm{l})$ in goat milk. Lower concentration of potassium concentrations in milk of goats compared with some authors may be due to different breed or the offered feed and the grazing. Sanz Ceballos et al. (2009) Milk composition of goats depends on the feed, breed, lactation stage, individual animal, status of udder health and other environmental factor. There is a significant difference $(P<0.05)$ between winter and summer season of potassium concentrations in milk of Boer and Baladi goats Table (5). Guler (2007) reported that the difference in concentrations of milk mineral within winter and spring season is due to effect of dilution.

Table 5. Mean \pm SE (mg/l ) of potassium in milk of ewes and goats during summer and winter season.

\begin{tabular}{|c|c|c|c|}
\hline \multirow{2}{*}{ Breed } & \multicolumn{2}{|c|}{ season } & \multirow{2}{*}{$\begin{array}{c}\text { Overall } \\
\text { mean }\end{array}$} \\
\hline & Summer & Winter & \\
\hline $\begin{array}{l}\text { Awassi } \\
\text { Baladi }\end{array}$ & \multicolumn{3}{|c|}{ 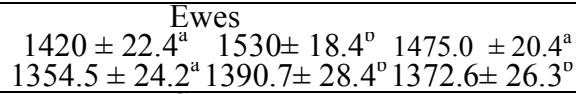 } \\
\hline & \multicolumn{2}{|c|}{ Goats } & \\
\hline Boer & $1560.6 \pm 17.9$ & $1760 \pm 21.2^{\mathrm{b}}$ & $\begin{array}{c}1660.3^{\mathrm{a}} \pm \\
19.5^{\mathrm{a}}\end{array}$ \\
\hline Baladi & $1432.3 \pm 11.9$ & $\begin{array}{c}1590.6^{ \pm} \\
13.9^{\mathrm{b}}\end{array}$ & $\begin{array}{c}1511.5^{ \pm} \\
13.9^{\mathrm{b}}\end{array}$ \\
\hline
\end{tabular}

${ }^{\text {a, b}}$ : values within the same row having different superscripts are significantly different at $(P<0.05)$.

\section{Copper concentrations in milk of ewes}

Copper concentrations in milk of ewes are shown in Table (6). Concentrations of copper in milk of Awassi ewes were higher $(0.740 \pm 0.15 \mathrm{mg} / \mathrm{l})$ compared with Baladi ewes $(0.442 \pm 0.20 \mathrm{mg} / \mathrm{l})(P<0.05)$. The present means of copper concentrations are closed to that reported by Raynal-Ljutovac et al. (2008), Etonihu and Alicho (2010) and Zamberlin et al. (2012) (0.40- $0.89 \mathrm{mg} / \mathrm{l})$ in milk of ewes. Higher concentrations of copper were reported by Gerchev and Mihaylova (2012) (1.2 and 1.8 $\mathrm{mg} / \mathrm{l})$ in milk of ewes. On contrast, lower concentrations of copper were reported by Abdalla et al. (2013) and Elbagermi et al. (2014) (0.09 $-0.2 \mathrm{mg} / \mathrm{l})$ in milk of ewes. Copper concentrations in milk of ewes are significantly $(P$ $<0.05)$ higher in winter $(0.760 \pm 0.1 \mathrm{mg} / \mathrm{l})$ than in summer season $(0.720 \pm 0.2 \mathrm{mg} / \mathrm{l})$, respectively (Table, 6). Nantapo et al. (2013) reported higher concentration of copper in milk during cold months $(0.20 \mathrm{mg} / \mathrm{l})$ than hot months $(0.17$ mg/l). Park et al. (2007) and Sanz Ceballos et al. (2009) reported that milk composition of ewes and goats depends on the breed, feeding, lactation stage, individual variations, status of udder health and environmental factors.

\section{Copper concentrations in milk of goats}

Copper concentrations in milk of goats are shown in Table (6). Concentrations of copper in milk of Boer goats were higher $(0.718 \pm 0.25 \mathrm{mg} / \mathrm{l})$ compared with Baladi goats $(0.426 \pm 0.30 \mathrm{mg} / 1)(P<0.05)$. The present means are closed to that reported by Kondyli et al. (2007), Abed AlHelaly et al. (2013) and El-bagermi et al. (2014) ( 0.37- 0.8 $\mathrm{mg} / \mathrm{l})$ in milk of goats. On the contrary, lower concentrations of copper were reported by Zamberlin et al. (2012) and Abdalla et al. (2013) (0.1mg/l) in goats of milk. Higher concentrations of copper in goats milk were reported by Hernandz and Park (2014) (9.8 -10.5 mg/l). Concentrations of copper during winter season were significantly $(P<0.05)$ higher $(0.734 \pm 0.2,0.430 \pm 0.3$ $\mathrm{mg} / \mathrm{l})$ than summer $(0.702 \pm 0.3,0.422 \pm 0.3 \mathrm{mg} / \mathrm{l})$ season in two breed Boer and Baladi goats respectively. Concentration of copper in milk of goat during winter season was higher $(P<0.05)$ than summer season Table (6). Similar results were reported by Khan et al. (2003) and Kędzierska-Matysek et al. (2013). Michlova et al. (2016) found that the variation in concentrations of goat's milk minerals might be due to feed and pasture quality, throughout the different grazing seasons.

Table 6. Mean \pm SE (mg/l ) of copper in milk of ewes and goats during summer and winter season.

\begin{tabular}{|c|c|c|c|}
\hline \multirow{2}{*}{ Breed } & \multicolumn{2}{|c|}{ season } & \multirow{2}{*}{$\begin{array}{c}\text { Overall } \\
\text { mean }\end{array}$} \\
\hline & Summer & Winter & \\
\hline \multirow{3}{*}{$\begin{array}{l}\text { Awassi } \\
\text { Baladi }\end{array}$} & \multicolumn{2}{|c|}{ Ewes } & \multirow{3}{*}{$\begin{array}{l}0.740 \pm 0.15^{\mathrm{a}} \\
0.442 \pm 0.20^{\mathrm{D}}\end{array}$} \\
\hline & $0.720 \pm 0.2$ & $0.760 \pm 0.1^{\mathrm{D}}$ & \\
\hline & $0.434 \pm 0.2$ & $0.450 \pm 0.2^{\mathrm{D}}$ & \\
\hline \multirow[b]{2}{*}{$\begin{array}{l}\text { Boer } \\
\text { Baladi }\end{array}$} & \multicolumn{2}{|c|}{ Goats } & \multirow{2}{*}{$\begin{array}{l}0.718 \pm 0.25^{\mathrm{a}} \\
0.426 \pm 0.30^{\mathrm{D}}\end{array}$} \\
\hline & $\begin{array}{l}0.702 \pm 0.3^{\mathrm{a}} \\
0.422 \pm 0.3^{\mathrm{a}}\end{array}$ & $\begin{array}{l}0.734 \pm 0.2^{\mathrm{D}} \\
0.430 \pm 0.3^{\mathrm{D}}\end{array}$ & \\
\hline a, balu & & . & \\
\hline
\end{tabular}

\section{Zinc concentrations in milk of ewes}

Concentrations of zinc in milk of ewes are presented in Table (7). Concentrations of zinc in milk were higher $(6.8 \pm 0.7 \mathrm{mg} / \mathrm{l})$ of Awassi ewes compared with Baladi ewes $(5.4 \pm 0.6 \mathrm{mg} / \mathrm{l})(P<0.05)$. The present means were closed to that reported by Gerchev and Mihaylova 
(2012) and El-Bagermi et al. (2014) (5.4 - $7.1 \mathrm{mg} / \mathrm{l})$. Lower concentrations reported by Abdalla et al.(2013) and Abed Al-Helaly et al. (2013) (0.24 - 0.79 mg/l) respectively. On contrast, higher concentrate reported by Goran et al. (2010) $(9.5 \mathrm{mg} / \mathrm{l})$. In the present study the lower concentrations of zinc in milk of ewes compared some authors may be due to dietary levels of zinc in two experiments (Underwood, 1981). Zinc concentrations were higher $(P<0.05)$ in winter season $(7.2 \pm 0.8,6.4 \pm 0.6$ $\mathrm{mg} / \mathrm{l})$ than summer season $(5.7 \pm 0.7,5.1 \pm 0.5 \mathrm{mg} / \mathrm{l})$ in two breed Awassi and Baladi ewes. This results agrees with that reported by Khan et al. (2003), who found that concentrations of zinc in milk in the cold season was higher $(1.29 \mathrm{mg} / \mathrm{l})$ than hot season $(0.56 \mathrm{mg} / \mathrm{l})$ in sheep.

\section{Zinc concentrations in milk of goats}

Concentrations of zinc in milk of goats are presented in Table (7). Concentrations of zinc in milk were higher $(3.2 \pm 0.3 \mathrm{mg} / \mathrm{l})$ of Boer goats compared with Baladi goats $(2.7 \pm 0.3 \mathrm{mg} / \mathrm{l})(P<0.05)$. The present means are closed to that reported by Kondyli et al. (2007) and Zamberlin et al. (2012) (2.4 - $3.7 \mathrm{mg} / \mathrm{l})$ in milk goats, but the means were lower compared with that reported by Hernandz and Park (2014) (11.7 - 17.5 $\mathrm{mg} / \mathrm{l})$. Opposite trend, reported by Abed Al-Helaly et al. (2013) and Abdalla et al. (2013) found low concentrations of zinc in milk ewes $(0.99-1.24 \mathrm{mg} / \mathrm{l})$. Concentrations of zinc were higher $(P<0.05)$ in winter season $(3.3 \pm 0.5,2.9 \pm 0.3 \mathrm{mg} / \mathrm{l})$ than summer season $(3.1 \pm 0.2,2.4 \pm 0.4 \mathrm{mg} / \mathrm{l})$ in two breed Boer and Baladi goats. Similar trend was reported by Bartowska et al. (2013) who found that seasonal variations of mineral in goat's milk might be due to the fluctuations in goats feeding during the different grazing season.

Table 7. Mean $\pm \mathrm{SE}(\mathrm{mg} / \mathrm{l})$ of zinc in milk of ewes and goats during summer and winter season.

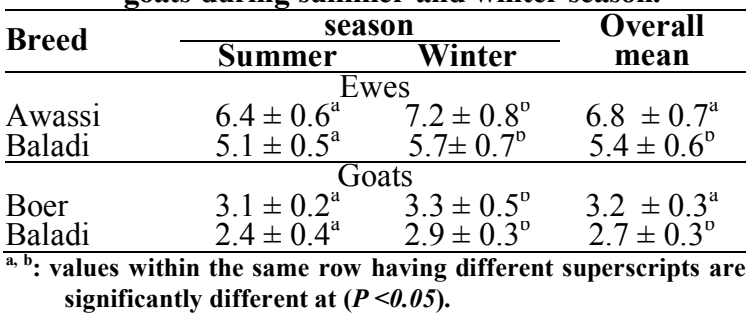

2-Minerals concentrations in blood plasma of ewes and goats

Sodium concentrations in blood plasma of ewes

Concentrations of sodium in blood plasma of ewes are presented in Figure (1). Concentrations of sodium in blood plasma of Awassi ewes were significantly higher $(2321.5 \pm 10.8 \mathrm{mg} / \mathrm{l})$ compared with Baladi ewes $(2034.3 \pm 8.8 \mathrm{mg} / \mathrm{l})(P<0.05)$. The obtained means were agrees with that reported by Sowande et al. (2008) $(2326.9 \mathrm{mg} / \mathrm{l})$, but the mean was higher than that reported by Ebrahim et al. (2016) (1090.5 mg/l). While the obtained mean was lower than that reported by Hassabo et al. (2015) (2648.9 mg/l) in plasma of sheep. The different results may be due to the breed, feed or status of ewes during the experiment. Macro-mineral status in ewes change during oestrous cycle, pregnancy, at lambing, post-lambing lactation days (Bonchev, 1985 and Bhatt et al.,1996). Concentrations of sodium in blood plasma was higher $(P<0.05)$ in winter season than summer season, this results agree with that reported by Khan et al. (2003) and Sowande et al. (2008) who found higher concentration of sodium in blood plasma during the winter season compared to summer season in sheep. This result may be due to increased loss more quantity of sodium by sweating throughout the summer season.

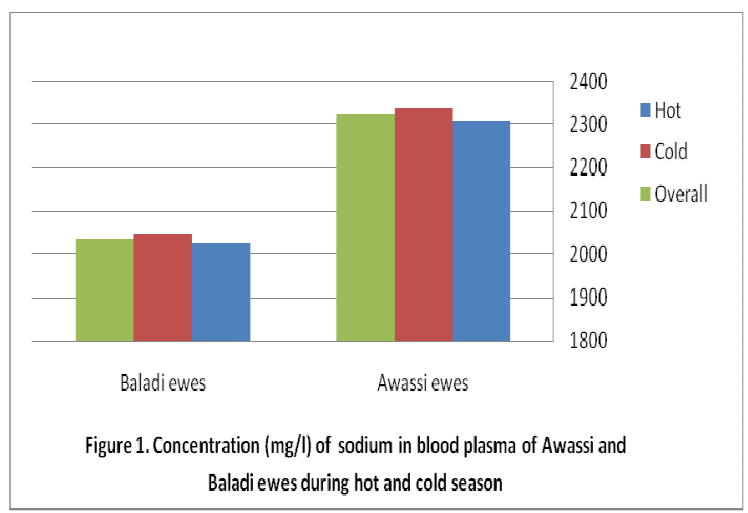

Sodium concentrations in blood plasma of goats

Sodium concentrations in blood plasma of goats are presented in Figure (2). From figure (2) concentrations of sodium in blood plasma of Boer goats was higher compared with Baladi goats $(P<0.05)$. The obtained means of Boer goats were agreement with that reported by Altug et al. (2013) and Hafid et al. (2013) $(3266.0$ - $3268.3 \mathrm{mg} / \mathrm{l})$, but the means of Baladi goats were lower might be due to breed difference, feed and pasture. Sodium concentrations in blood plasma was higher $(\mathrm{P}<0.05)$ in winter season than summer season, similar trend, reported by Khan et al. (2003) and Sowande et al. (2008) who found that sodium concentrations in blood plasma was higher during the winter season than summer season in sheep. This result may be due to increased the sweating and loss more quantity of sodium in the summer season.

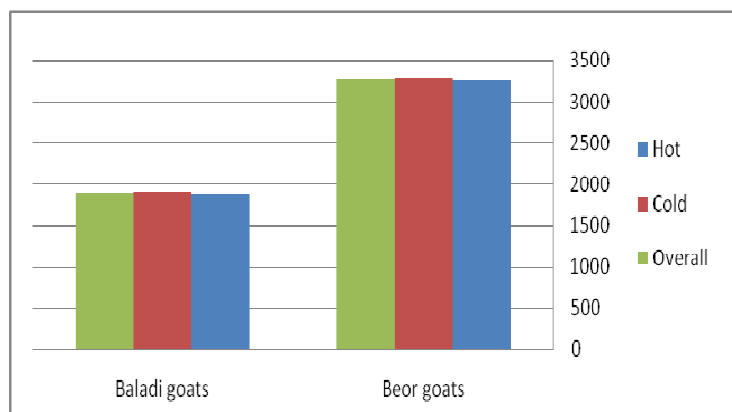

Figure 2. Concentrations $(\mathrm{mg} / \mathrm{l})$ of sodium in blood plasma of Boer and Baladi goats during hot and cold season

\section{Potassium concentrations in blood plasma of ewes}

Potassium concentrations in blood plasma of ewes are presented in Figure (3). Figure (3) indicate higher concentrations of potassium in blood plasma of Awassi ewes compared with Baladi ewes $(P<0.05)$. This means agree with that reported by Sowande et al. (2008) $(208.3 \mathrm{mg} / \mathrm{l})$ in sheep. The means were higher than that reported by Ebrahim et al. (2016) (40.05 mg/1). 
this different result might be due to differences of breed or content of minerals in feed. Potassium concentrations in blood plasma was higher $(\mathrm{P}<0.05)$ in winter season than summer season, similar finding, reported by Khan et al. (2003) and Sowande et al.(2008) found that potassium concentrations in blood plasma during winter season were higher than summer season the in sheep.

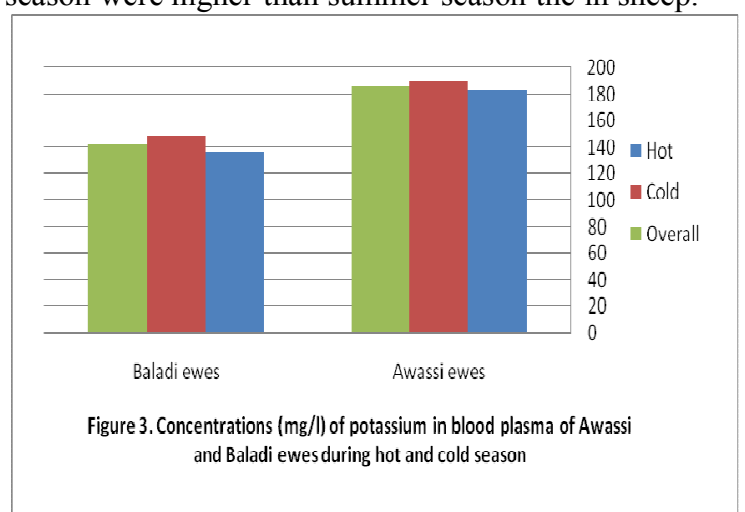

Potassium concentrations in blood plasma of goats

Potassium concentrations in blood plasma of goats are presented in Figure (4). Concentrations of potassium of Boer goats was higher compared with Baladi goats $(P<0.05)$ Figure $(4)$. The means of potassium of two breed were agreement with that reported by Al-Sobiyl (2010) and Altug et al. (2013) (138.9 -206.7 mg/l) in sheep. On contrary, higher concentrations were reported by Hafid et al. (2013) $250.8 \mathrm{mg} / 1$ in ewes. Potassium concentrations in blood plasma of goats were higher $(\mathrm{P}<0.05)$ during the winter than summer season. The result was agreement with that reported by Khan et al. (2003) who found potassium concentrations in blood plasma was higher during the winter season than summer.

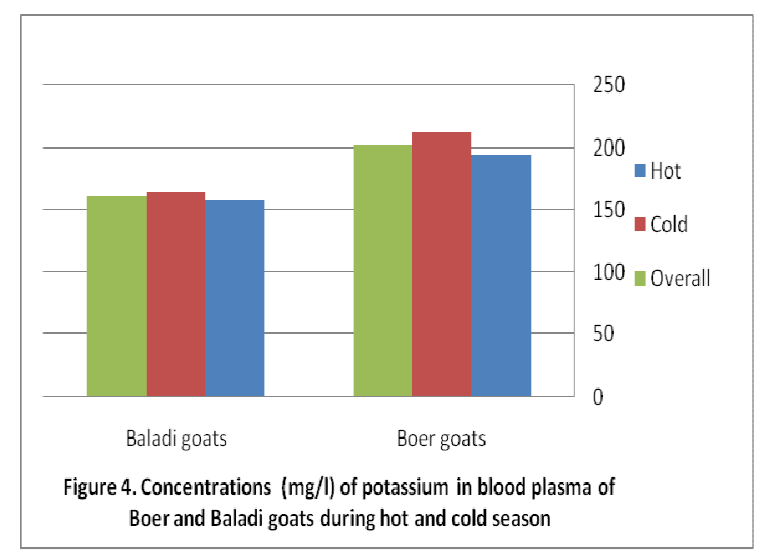

Copper concentrations in blood plasma of ewes

Copper concentrations in blood plasma of ewes were shown in Figure (5). Concentrations of copper in blood plasma of Awassi ewes were higher compared with Baladi ewes $(P<0.05)$, Figure $(5)$. The obtained means were agree with that reported by Hajer et al. (2014) and Nawito et al. (2015) $(0.44-0.84 \mathrm{mg} / \mathrm{l})$ in ewes, but the means was lower than that reported by Ebrahim et al. (2016) and Samadieh et al. (2017) (1.01 - $1.09 \mathrm{mg} / \mathrm{l})$ in sheep. Copper concentrations were higher $(\mathrm{P}<0.05)$ in winter season compared with summer season in the two breeds. Similar trend reported by Dar et al. (2014) and Bafti (2016) in sheep. Khan et al. (2003) reported that in ewes copper concentrations in blood plasma was higher during the winter season than summer.

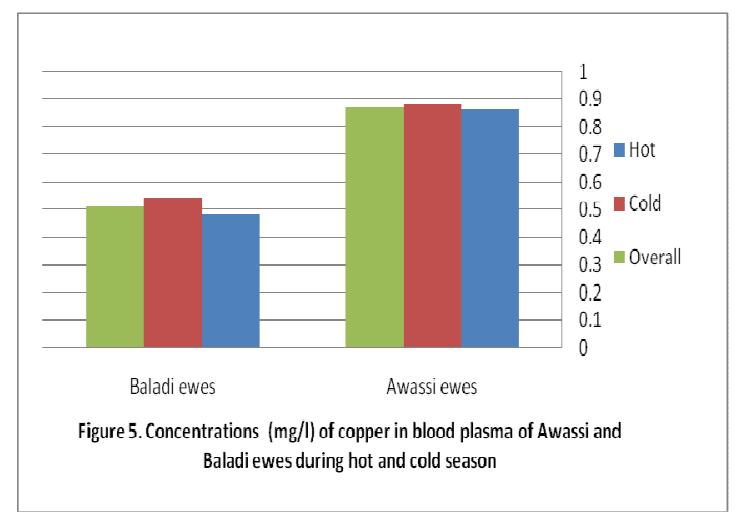

\section{Copper concentrations in blood plasma of goats}

Copper concentrations in blood plasma were shown in Figure (6). Concentrations of copper in blood plasma of ewes of Boer goats were higher compared with Baladi goats $(P<0.05)$ Figure $(6)$. The means of copper were closed to that reported by Altug et al. (2013), Yatoo et al. (2013) and Hajer et al. (2014) (0.55 $-0.88 \mathrm{mg} / \mathrm{l})$ in sheep, while the means were higher than that reported by Al-Sobaiyl (2010) and Nawito et al. (2015) 0.15 and $0.4 \mathrm{mg} / 1$ respectively. Copper concentrations were higher $(\mathrm{P}<0.05)$ in winter season compared with summer season in the two breeds of goats. Khan et al. (2008) and Bafti (2016) found that in goats serum copper concentration was higher during autumn than spring and summer. Similar trend was reported by Khan et al. (2003) who observed that in goats copper concentrations in blood plasma was higher during the winter season than summer.

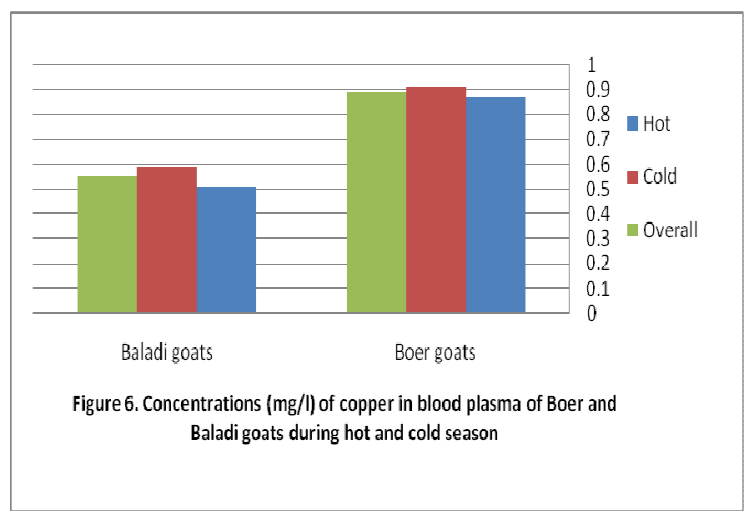

\section{Zinc concentrations in blood plasma of ewes}

Zinc concentrations in blood plasma of ewes were shown in Figure (7). Concentrations of zinc in blood plasma of Awassi ewes were higher compared with Baladi ewes $(P<0.05)$ Figure (7). The means were closed to that reported by Ebrahim et al. (2016) and Samadieh et al. (2017) 0.58 and $1.79 \mathrm{mg} / \mathrm{l}$ respectively. Higher concentration of zinc in sheep milk was reported by Nawito et al. (2015) 4.3mg/l. The different result might be 
due to differences of breed or content of minerals in feed or grazing. Zinc concentrations were higher $(\mathrm{P}<0.05)$ in winter season compared with summer season in two breeds of ewes. Similar trend, reported by Khan et al. (2008) and Dar et al. (2014) found that plasma copper concentration was higher during winter than summer season in ewes. Khan et al. (2003) observed that in ewes zinc concentrations in blood plasma was higher during the winter season than summer season.

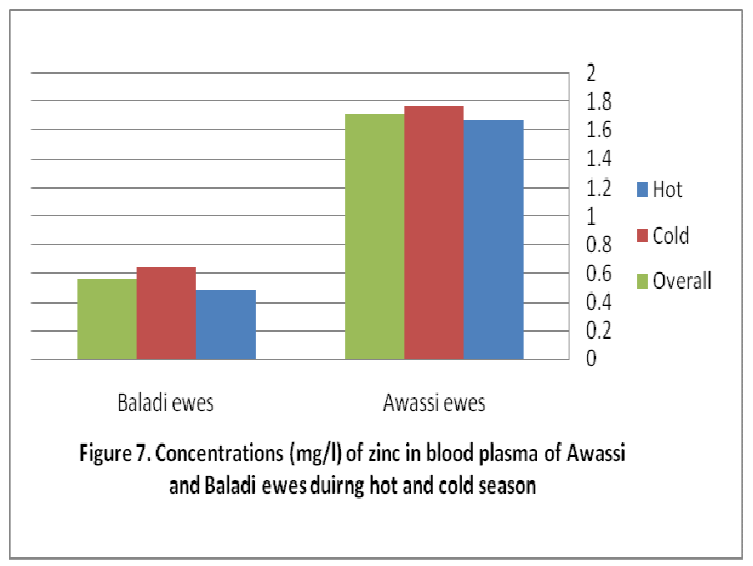

\section{Zinc concentrations in blood plasma of goats}

Zinc concentrations in blood plasma of goats were shown in Figure (8). Concentrations of zinc in blood plasma of Boer goats were higher compared with Baladi goats $(P<0.05)$ Figure $(8)$. The present means are in agreement with that reported by Altug et al. (2013) and Hajer et al. (2014) found that concentration of zinc in serum and plasma was 0.57 and $1.2 \mathrm{mg} / \mathrm{l}$ respectively. On contrast, higher concentration of zinc was reported by Donia et al. (2014) and Nawito et al. (2015) (4.01 - 5.9 $\mathrm{mg} / \mathrm{l}$ ) in ewes. In the present study the lower concentrations of zinc in blood plasma of goats compared some another authors may be due to dietary levels of zinc in two experiments (Underwood, 1981). Zinc concentrations were higher $(\mathrm{P}<0.05)$ in winter season compared with summer season in two breeds of goats. Similar trend, reported by Khan et al. (2008) who found seasonal variations in blood minerals in goats.

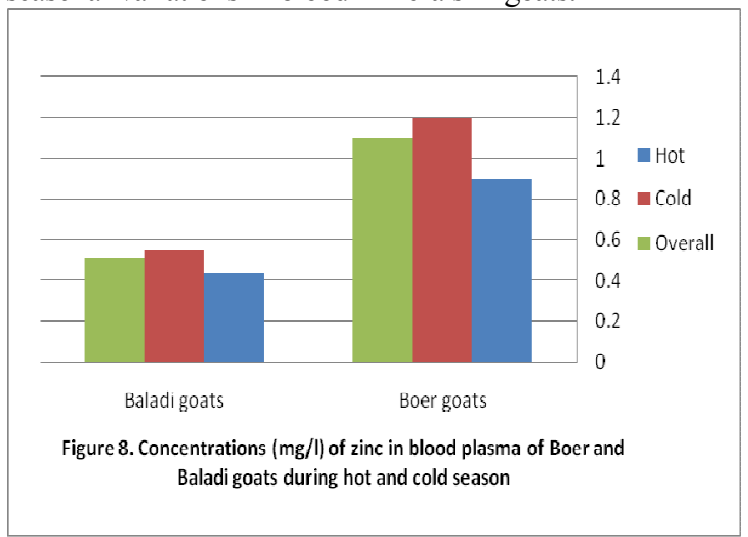

3-Correlation coefficient ( $r$ ) of sodium, potassium, copper and zinc in blood and milk of Awassi, Baladi ewes and Boer, Baladi goats.

Correlation coefficients of sodium, potassium, copper and zinc in blood and milk of Awassi, Baladi ewes and Boer, Baladi goats are presented in Table (8). In Awassi ewes milk copper was significantly negatively correlated $(-\mathrm{r}=567, \mathrm{P}<0.05)$ with blood plasma copper. While, significantly and positively correlated $(\mathrm{r}=0.788$, $0.657 \mathrm{P}<0.05$ ) was showed among milk zinc and blood plasma zinc in Awassi and Baladi ewes respectively. Nonsignificant negative correlation was found for sodium and potassium in blood plasma and milk in Awassi and Baladi ewes Table (8). Positive correlation was observed in Boer and Baladi goats milk sodium, potassium and copper and blood plasma Table (8), but milk zinc was positively correlated with blood plasma in Boer and Baladi goats. Similar trend was reported by Ranjith and Pandey (2015) in Deccani sheep.

Table 8. Correlation coefficient ( $r$ ) of sodium, potassium, copper and zinc in blood and milk of Awassi, Baladi ewes and Boer, Baladi goats.

\begin{tabular}{|c|c|c|c|c|c|}
\hline \multirow{3}{*}{$\begin{array}{l}\text { Minerals } \\
\text { in blood }\end{array}$} & \multirow{3}{*}{$\begin{array}{c}\text { Minerals } \\
\text { in milk }\end{array}$} & \multicolumn{4}{|c|}{ Correlation coefficient $(r$ ) } \\
\hline & & \multicolumn{2}{|c|}{ Ewes } & \multicolumn{2}{|c|}{ Goats } \\
\hline & & Awassi & Baladi & Boer & Baladi \\
\hline Sodium & & -0.307 & -0.287 & -0.233 & -0.224 \\
\hline & Potass & -0.187 & -0.165 & -0.211 & -0.155 \\
\hline Copper & Copper & -0.567 & -0.434 & -0.467 & -0.345 \\
\hline & & 0.788 & 0.657 & 0.675 & 0.643 \\
\hline
\end{tabular}

"values with having superscripts are significantly different at $(\mathbf{P}<\mathbf{0 . 0 5})$.

\section{CONCLUSION}

The present results display that concentrations of sodium, potassium, copper and zinc in milk and blood plasma were higher in Awassi ewes and Boer goats compared with Baladi ewes and goats. Concentrations of studied elements in milk and blood plasma during the hot season recorded lower levels than cold season in ewes and goats. Thus the results recommended supplementation of mixture of salts to diet of animals during the hot season in order to conservation of the minerals concentration in the normal levels in milk or blood. In addition, the assay of the studied minerals (sodium, potassium, copper and zinc) in milk compared with blood plasma is more easy and also accurate in ewes and goats.

\section{REFERENCES}

Abdalla, M. O. M.; A. A. Hassabo and N. A. H. Elsheikh (2013). Assessment of some heavy metals in waste water and milk of animals grazed around sugar cane plants in Sudan. Livestock Research for Rural Development, 25 (12).

Abed Al-Helaly, L.; S. H. Rashed and L. F. Bdaiwi (2013). A comparative study of oxidant and antioxidant levels between human milk with other types of ruminant animals. Iraqi Nat. J. Chem., 49: 86-99.

Ahmed, M. M. M.; A. Khalid; M. E. Siham and S. Barri (2000). Macromineral profile in plasma of Nubian goat as affected by physiological state. Small Rumin. Res., 38: 249-254.

Al-Sobaiyl, K. A. (2010). Effect of breeding season and pregnancy status on serum progesterone, sodium, potassium, copper and iron of estrous synchronized Aradi goat does. Saudi Journal of Biological Sciences, 17: 259-263. 
Altug, N.; S. A. N. Yuksek; I. Keles; I. H. Yoruk; Y. Basbugan and I. Aytekin (2013). The levels of trace elements and selected vitamins in goats with chronic fluorosis, Turk J Vet Anim. Sci., 37: 529534.

AOAC, ( 2000). Official Methods of Analysis. 17th Edition. Gaithersburg, Maryland, USA.

Bafti, M. S. (2016). Seasonal variations of serum copper concentration in Raeini cashmere goats. Journal of Livestock Science and Technologies, 4 (1): 33-38.

Bartowska J.; A. Wolanciuk; M. Kędzierska-Matysek and Z. Litwinczuk (2013). Effect of production season on the basic chemical composition and content of macro- and microelements in cow and goat milk. Zywn. Nauk. Technol. Jak., 6 (91): 69-78.

Bhatt, R.; A. K. Shinde; S. A. Karim and B.C. Patnayak (1996). Plane of nutrition in malpura and mutton synthetic ewes maintained on conchrus ciliaris pasture during different physiological stages. Indian J. Anim. Sci., 66(6):614-618.

Bonchev, S. (1985) Ca, P, Mg, Na, Fe and $\mathrm{Cu}$ in blood serum of ewes of different ages in relation to physiological condition. Vet. Bull., 55(4):784.

Casey, N. H. and W. A. Van Nierkerk (1988). The Boer goat. I. Origin, adaptability, performance testing, reproduction and milk production. Small Rumin. Res., 1: 291-302

Catarino, I; P. L. Martins; A. P. L.,E. Duarte; E. S. Prudêncio and M. N. De Pinho (2013). Rennet coagulation of sheep milk processed by ultra filtration at low concentration factors. Journal of Food Engineering, 114: 249-254.

Dar, A. A.; R. K. Jadhav; U. Dimri; A. A. Khan; H. M. Khan and M. C. Sharma (2014). Effects of physiological status and seasonal variation on plasma mineral profile of sheep in Kashmir valley. Scientific Research and Essays, 9(4): 69-76.

Donia, G.R.; N. H. Ibrahim; Y. M. Shaker; F. M. Younis and H. Z. Amer (2014). Liver and Kidney Functions and Blood Minerals of Shami Goats Fed Salt Tolerant Plants under the Arid Conditions of Southern Sinai, Egypt Journal of American Science, $10(3): 1-11$.

Ebrahim, Z. K.; A. A. Goma and M. A. Lebda (2016). Behavioral and biochemical alterations in sheep with trace elements deficiency: a trial for treatment. American Journal of Life Science Researches, 4 (2): 55- 61.

El-bagermi, M. A.; H. G. M. Edwards and A. I. Alajtal (2014). A comparative study on the physicochemical parameters and trace elements in raw milk samples collected from Misurata- Libya. SOP Transactions on Analytical Chemistry, 1 (2):15-23.

Erasmus, J. A. (2000). Adaptation to various environments and resistance to disease of the improved Boer goat. Small Rumin. Res., 36: 179-187.

Etonihu, A. C. and J. O. Alicho (2010). Proximate and heavy metal compositions of milk from ewe, cow, goat, and human. Sciencia Acta Xaveriana, 1 (2): $41-50$.
Gerchev, G. and G. Mihaylova (2012). Milk yield and chemical composition of sheep milk in Srednostaro planinska and Tetevenska breeds. Biotechnology in Animal Husbandry, 28 (2): 241251.

Goran, G. V.; V. Crivinean; E. Rotaru; L. Tudoreanu and A. Hanganu (2010). Dynamics of some mineral elements in sheep colostrum. Bulletin UASVM, Veterinary Medicine, 67(2): 81- 87.

Guler, Z.; (2007). Levels of 24 minerals in local goat milk, its strained yoghurt and salted yoghurt (tuzlu yogurt). Small Rumin. Res., 71: 130-137.

Güzeler, N.; D. Say and A. Kacar (2010). Compositional changes of Sannen X Kilis goats milk during lactation. GIDA, 35 (5): 325-330.

Hafid, N., T. Meziane, B. Maamache andM. Belkhiri, 2013. Biochemical and mineral profile of south Eastern Algerian desert goats (Capra hircus). Iranian Journal of Applied Animal Science, 3(3): 527-531.

Hajer, I.; I. Ishraga; G. Ibrahim; A. M. Shamat; A. Aisha and S. H. Eisa (2014). Mineral profile of sheep and goats grazed natural pasture in Nyala locality, Western Sudan. Journal of Agricultural and Veterinary Sciences, 15(1):53-61.

Hassabo; A. M.; M. A. El Hag; M. O. Eisa and A. F. B. Sallam (2015). Sodium and chloride in soil, feed and sheep plasma of West Kordofan, Sudan as influenced by growth stages. International Journal of Animal Biology, 1 (1): 6-10.

Hernandez, K. and Y. W. Park (2014). Evaluation of 20 macro and trace mineral concentrations in commercial goat milk yogurt and its cow milk counterpart. Food and Nutrition Science, 5: 889895.

Kedzierska -Matysek ; M. J. Barłowska ; Z. Litwińczuk and N. Koperska (2013). Content of macro- and microelements in goat milk in relation to the lactation stage and region of production. J. Elem. s., 107-114.

Khan, Z. I.; K. Ahmed; M. Ashraf; E. E. Valeem and I. Javed (2008). A comparative study on mineral status of blood plasma of small ruminants and pastures in Punjab, Pakistan. Pak. J. Bot., 41:67-72.

Khan, Z. I.; M. Ashraf; M. Y. Ashraf; Z. Rahman and A. Hussain (2003). Mineral status of livestock (goats and sheep) based on soil, dietary components and animal tissue fluids in relation to seasonal changes and sampling period in specific region of Pakistan. J. Anim. Vet. Adv., 2: (8): 478- 495.

Kondyli, E.; M. C. Katsiari and L. P. Voutsinas (2007). Variations of vitamin and mineral contents in raw goat milk of the indigenous Greek breed during lactation. Food Chem., 100(1):226-30.

Krajnicakova, M.; G. Kovac; M. Kostecky; I. Valocky; I. Maracek; I. Sutiakova and L. Lengardt (2003). Selected clinico-biochemical parameters in puerperal period of goats. Bull. Vet Inst. Pulawy, 47: 177-182.

McDowell, L. R. (1985). Nutrition of grazing ruminants in warm climates. Academic Press Inc. San Diego CA., p: 168-169. 
Michlova,T.; A. Hejtmankova; H. Dragounova and S. Hornickova (2016). The content of minerals in milk of small ruminants. Agro. Res., 14: 1407-1418.

Moreno-Rojas, R.; G. Zurera-Cosano and M. A. AmaroLopez (2009). Concentration and seasonal variation of calcium, magnesium, sodium and potassium in raw cow, ewe and goat milk. International Journal of Food Sciences and Nutrition, 45(2):99-105.

Nantapo, C. T. W. and V. Muchenje, (2013). Winter and spring variation in daily milk yield and mineral composition of Jersey, Friesian cows and their crosses under a pasture-based dairy system. South African Journal of Animal Science, 43 (5) 17- 21.

National Research Council (1980). Mineral Tolerance of Domestic Animals, Washington, D.C. National Academy of Sciences.

Nawito, M. F., K. G. M. Mahmoud; M. M. M. Kandiel; Y. F. Ahmed and A. S. A. Sosa (2015). Effect of reproductive status on body condition score, progesterone concentration and trace minerals in sheep and goats reared in South Sinai, Egypt. African Journal of Biotechnology, 14(43):30013005.

Ojoawo, O. T and A. O. Akinsoyinu (2104). Sodium, potassium and magnesium in milk of West African Dwarf does as influenced by lactation stages. Journal of Agriculture and Environmental Sciences, 3(2): 333-343.

Park, Y. W.; M. Juarez; M. Ramos and G. F. W. Haenlein (2007). Physico-chemical characteristics of goat and sheep milk. Small Rumin Res., 68(1-2): 88-113.

Ranjith, D. and J. K. Pandey (2015). Mineral Profiles in Blood and Milk of Sheep . International Journal of Science and Research, 4 (10): 821-826.

Raynal-Ljutovac, K.; G. Lagriffoul; P. Paccard; I. Guillet and Y. Chilliard ( 2008). Composition of goat and sheep milk products. Small Rumin. Res., 79 (1):5772.
Sahan; N. D. Say and A. Kacar (2005). Changes in chemical and mineral contents of Awassi ewes milk during lactation. Turk J Vet Anim Sci., 29: 589-593.

Samadieh, H.; G. R. Mohammadi; M. Maleki; H. Borji; M. Azizzadeh and M. Heidarpour (2017). Relationships between oxidative stress, liver, and erythrocyte injury, trace elements and parasite burden in sheep naturally infected with Dicrocoelium dendriticum. Iran J Parasitol, 12 (1): 46-55.

Sanz Ceballos, L. S.; E. R. Morales; G. de la Torre Adarve; J. D. Castro; L. P. Martinez and M. R. Sanz Sampelayo (2009). Composition of goat and cow milk produced under similar conditions and analyzed by identical methodology. Journal of Food Composition and Analysis, 22: 322-329.

SAS (2002). User's Guide: Statistics, Version 9.0 Edition. SAS Institute Inc., Cary, NC, USA.

Sowande, O. S.; E. B. Odufowora; A.O. Adelakun and L.T. Egbeyale (2008). Blood minerals in wad sheep and goats grazing natural pastures during wet and dry seasons. Arch. Zootec., 57 (218): 275-278.

Talafha, A. Q. and M. M. Ababneh (2011). Awassi sheep reproduction and milk production: review. Trop. Anim. Health. Prod. 43 (7):1319-1326.

Underwood, EJ.(1981) The mineral nutrition of livestock.2nd edn.(1981 CAB, London, pp. 3-127.

Yatoo , M. I.; A. Saxena; P. Kumar; M. B. Gugjoo; U. Dimri; M. C. Sharma and R. Jhambh (2013). Evaluation of serum mineral status and hormone profile in goats and some of their inter-relations. Vet. World, 6 (6):318-320.

Zamberlin, S.; N. Antunac; J. Havranek and D. Samaržija (2012). Mineral elements in milk and dairy products. Mljekarstvo. 62 (2):111-125.

\section{دراسة مقارنة تركيز بعض المعادن في اللبن وبلازما الام في الأغنام والماعز البلدية والأجنبية أثناء فترة مـا بعد

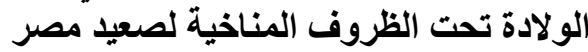

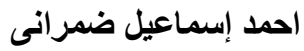 قسم الإنتاج الحيواني والديل فمرانى اجن, كلية الزراعة والموارد الطبيعية, جامعة أسوان, مصر}

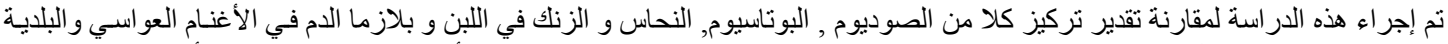

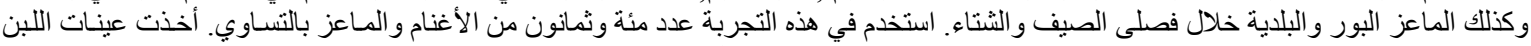

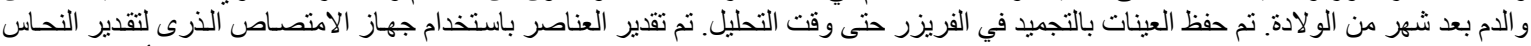

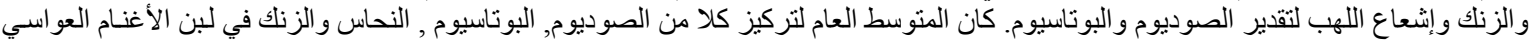

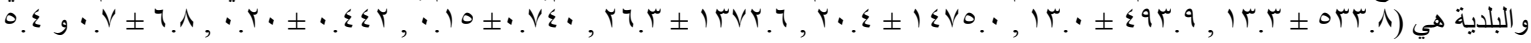

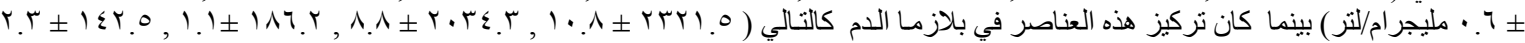

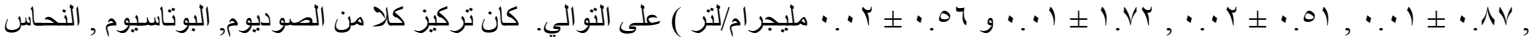

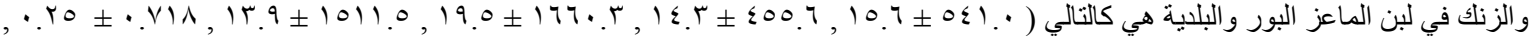

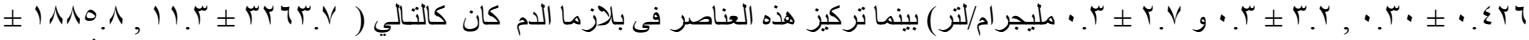

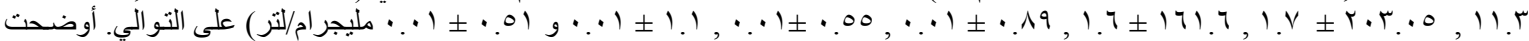

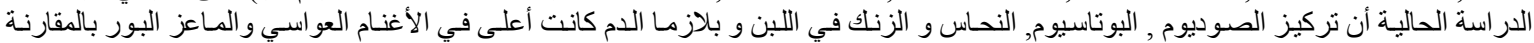

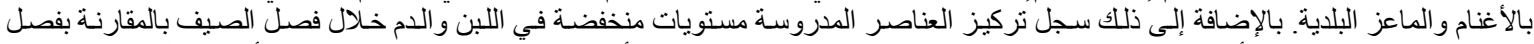

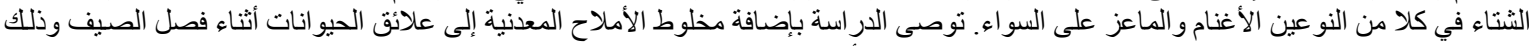

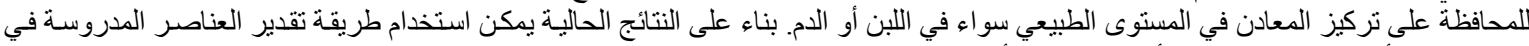

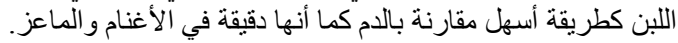

